\title{
The Impact of Youth Unemployment on the Zambian Economy
}

\author{
Francis Mukosa $^{1^{*}} \quad$ Moses Katebe $^{2} \quad$ Kwesi Sakyi $^{3} \quad$ Burton Mweemba ${ }^{4}$ \\ Serah Mbewe ${ }^{5}$ Webster Sikazwe ${ }^{6}$ \\ School of Business, ZCAS University, PO box 35243, Lusaka 10101, Zambia
}

\begin{abstract}
This research looks at the issue of youth unemployment and how this affects the Zambian economy. The paper focuses on examining how the productive age in Zambia has been disadvantaged by the introduction of some regulations and policies. The paper brings into perspective the shrinking employment opportunities for the youth and how this effects productivity in key economic sectors such as mining, agriculture and the private sector. The findings indicate that the increase in the pensionable age disadvantages the youth and further increases the unemployment rate for the youth and women. The findings have also brought out the challenges that are faced by the unemployed youth and how they have been forced to engage in crime and political violence in order for them to make a living. The youth in Zambia represent $60 \%$ of the total employable age yet instead of being in wellpaying and productive jobs; they are involved in crime, prostitution, drug abuse and alcohol abuse. The research outcomes also indicate that the definitions of a youth in the Zambian youth policy and the definitions of a youth by the United Nations are different and this may pose a challenge in terms of statistics and planning purposes. The paper takes a secondary research approach by reviewing research findings that have been drawn from analysing the different opinions, facts and findings from researchers on the topic of youth unemployment and government policies and laws on youth employment. Indicators from the findings are that youth unemployment is a global problem, which affects even rich countries such as the UK that has a huge GDP than that of Zambia. The conclusion in the paper is that there is a direct connection between youth unemployment and economic growth and that governments must ensure that they put youth employment at the centre of national economic planning.
\end{abstract}

Keywords: unemployment, youth, government, economy, policy, labour, productivity

DOI: $10.7176 / \mathrm{JESD} / 11-6-09$

Publication date:March $31^{\text {st }} 2020$

\section{Introduction}

Unemployment levels in Africa and many parts of Europe are predominantly high and have been set on the top agenda for many governments that have realized the need to tap into the productive age for economic value. The population of the young who are in full time education increased in the UK from $26 \%$ to $38 \%$ by 2007 , and this figure has been increasing by at least $1.5 \%$ every two years (Bell \& Blanchflower, 2009). This increase means that the unemployment rate also increases as more and more youth graduates are churned out from tertiary institutions into the labour market. This is the reason why youth unemployment has been increasing since 1995 and by 2010; it stood at 20\% (Petrongolo \& Reenen, 2011). In South Africa the youth graduate unemployment rate stood at $25.2 \%$ by 2013 (Oluwajodu, et al., 2015). In Zambia, the youth unemployment rate stands at $60 \%$ of the total employable population (Ministry of Labour, 2017). The Zambian youth unemployment rate is seen to be among the leading rates in Sub-Saharan Africa especially that the youth population in the bracket of 15-34 makes up a huge majority of the Zambian population at $65 \%$ (ILO, 2017). Figure 1 below shows the unemployment rate in Europe and presents youth Unemployment as a global challenge that governments have to place on top of their economic agendas.

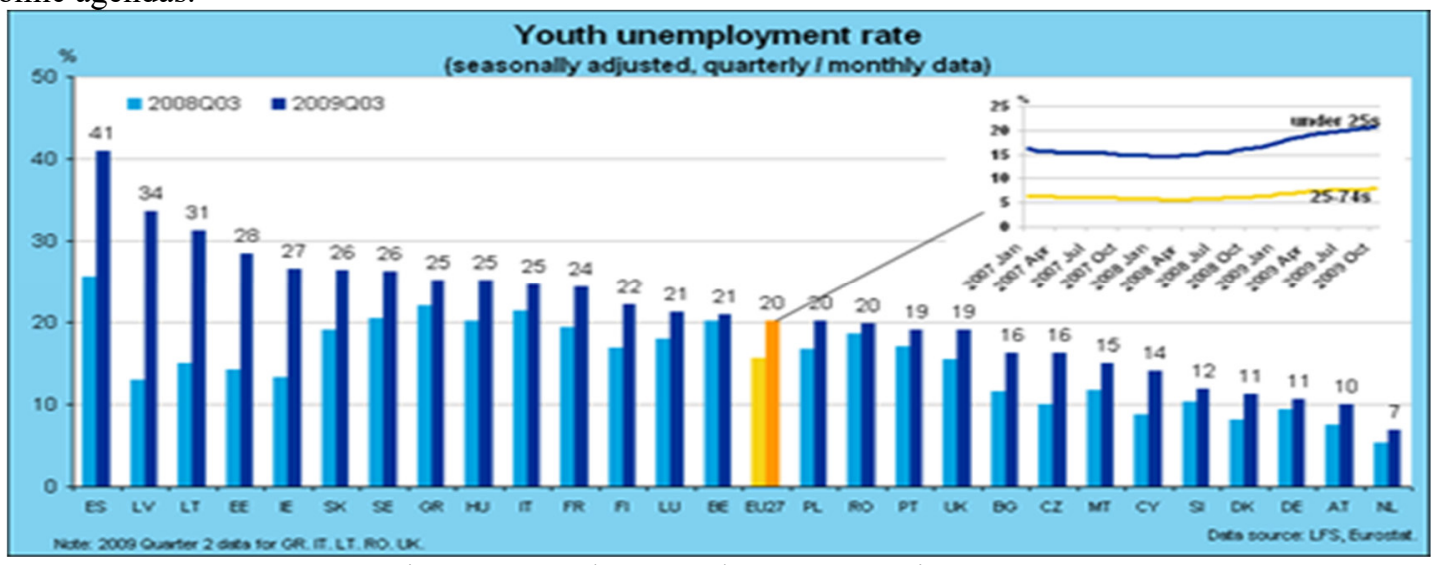

Figure 1: Youth Unemployment rates in Europe Source (Statista Data) 


\section{Definition of a Youth}

Zambia's national youth policy defines youth as anyone, male or female whose age is in between 18-35 years old (Ministry of youth and sport, 2015). This is somewhat different from the UN definition of a youth, which defines a youth as anyone between the ages of 15-24 (Ministry of youth and sport, 2015). The Zambian definition of the youth seems to raise the age of the youth at both the minimum age and the maximum age. The differences in the youth bracket in the writer's view seem to pose a huge challenge when it comes to global statistics and particularly those relating to youth employment. According to the ILO Report on Zambia, 57\% of the employable population in Zambia are regarded to be in employment and this figure includes those that are self-employed (ILO, 2017).

\section{Youth unemployment statistics}

The argument on the employment statistics in Zambia has always been that there has not been much formal employment creation by the government. In fact, the Ministry of Labour states that unemployment levels stand at $41.2 \%$ (Ministry of Labour, 2017). The youth in Zambia comprise $64.2 \%$ of the working population in Zambia and about $55.9 \%$ of the labour force (Bhorat, et al., 2015). The youth unemployment bracket of 15-34years represents $60 \%$ of the unemployed and this poses a huge challenge to national productivity (Haabazoka, et al., 2016). The problem of youth unemployment is not only in Zambia but also common in Kenya whose youth unemployment rate stands at $65 \%$ representing the highest among selected Sub-Saharan countries (Haabazoka, et al., 2016). Zambia's youth unemployment rate according to the research by Haabazoka et al, (2016) stands at $27.5 \%$. The comparison of Kenya youth unemployment rate to Zambia indicates that Zambia is better placed with its implementation of its national youth development policies but on the other hand an argument can be brought out that Kenya has a larger population of 48.46 million in comparison to Zambia with 16.6 million (World Bank, 2017). The differences in population indicate that the problems and challenges faced by Zambia in youth unemployment could have a larger effect on its economy than those faced by Kenya

\section{Zambia's GDP indicators}

Zambia's GDP has been growing since 2013 and indicates positive growth. This can be seen as a huge opportunity for employment creation for the youth. However, unfortunately, these indicators do to not seem like they are giving the youth a livelihood

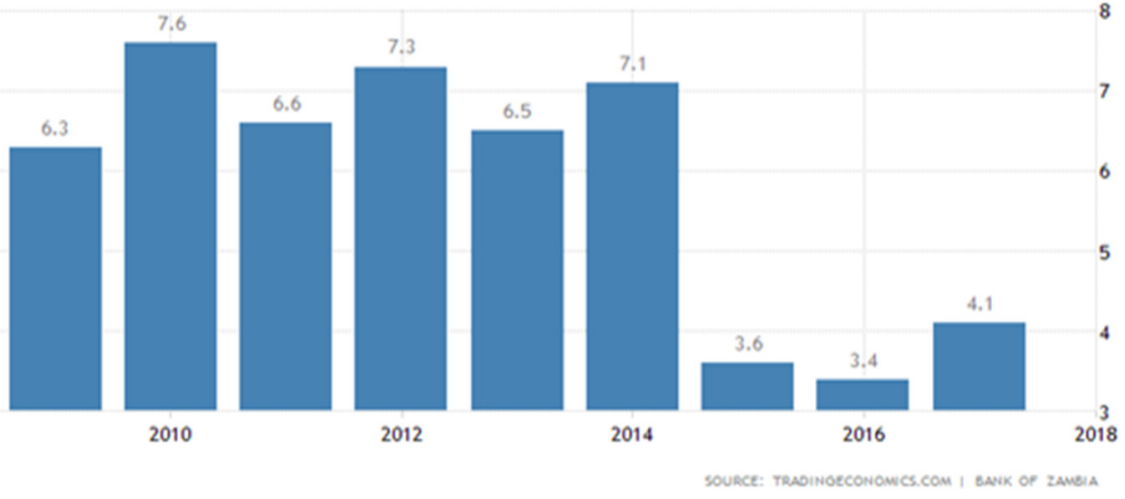

Figure 2: Zambia's GDP

\section{The challenges of youth unemployment}

Youth unemployment is a major political and socio-economic challenge in Africa, despite the efforts by some governments to try to enhance youth performance in their economies (Baah-Boateng, 2016). In Zambia, youth unemployment has been associated largely with crime and political violence. The lack of youth employment assumed to be the reason why many young people are involved in criminal activities and also involved in violent political crusades perpetrated by politicians in various political parties. A research by Caruso and Gavrilova analysed the relationship between unemployment and Violence in Pakistan. The findings indicated that most of the violence was stemming from the fact that many youths in that country were unemployed (Caruso \& Gavrilova, 2012).

The study in Pakistan appears to be one that can be compared largely to the Zambian environment where traces of political violence have been evident in every election in the last ten (10) years and involving the youth (Oliver, 2016). It is also clear that Zambia has not managed its elections and political conflicts well and hence many of the unemployed youth have been involved in political violence. Hilker in her research indicated that youth population is going to increase by 2025 and that the global youth population will stand at 72 million more (Hilker, 2015). According to Hilker the youth are mostly involved in violence and affected largely by poverty. This raises huge concerns for countries like Zambia with a relatively small GDP, as it means that the productive age group is 
not actively participating in economic growth activities.

\section{Youth Access to Capital}

The government of Zambia has created institutions such as the Citizens Economic Empowerment Commission (CEEC) program that has been supported with finances to provide working capital for the youth to enable them participate in entrepreneurship. A simple survey carried out around Lusaka reveals that many youth do not have access to capital through institutions such as the CEEC because of mainly two reasons; the first reason is related to corrupt activities and this is evident by the arrest of CEEC Directors in 2013 (Anti-corruption commission, 2013), the next reason is that they do not have the skills to prepare business plans that CEEC require in order to give them the business loans. Bank lending interests are also too high to enable the youth obtain bank loans to start businesses and often the banks require collateral security, which the majority of the youth do not have.

\section{Corruption and the youth}

Transparency International Zambia describes corruption in Zambia as endemic, and this is highly supported by the Auditor General's Report that indicated that corruption in Zambia is widely spread (Ndulo, 2014). Corruption in Zambia is linked to poor economic performance in Zambia and can be among the factors that are hindering youth employment in Zambia. This implies that sustainable jobs now become only accessible to the few privileged youth. Corruption can also be discussed in line with nepotism and gender abuse. There are cases in Zambia of young females who have been abused under pretence of getting those jobs.

\section{The Economic implications of youth unemployment in Zambia}

Zambia's GDP has been showing growth since 2010 and this growth is attributed to the increase in government expenditure that is reducing pressure on the economic performance of the currency due to availability of liquidity in the economy (Bloomberg, 2018). The increase in Zambia's GDP is largely attributed to copper prices stabilizing. It is trade with China and the economic boom in the construction industry that have seen cash flow injection into the economy. Economists have argued that the rebased currency indicates unrealistic economic indicators but this is rather a subject of debate.

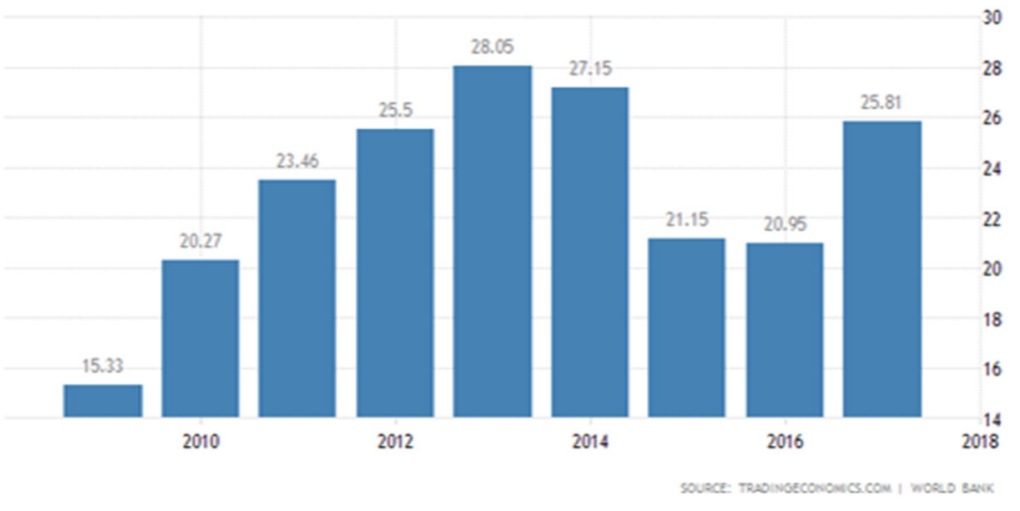

Figure 3: Zambia's GDP growth since 2010

Source: World Bank Trading Economics

The growth in Zambia's GDP should reflect an increase in employment including youth employment. However, the youth unemployment rates still remain high at $59.5 \%$ of the total employable youth population (ILO, 2017). The argument that Zambia's economic growth is unrealistic becomes visible with these indicators that are showing that the real growth sectors such as Agriculture and Mining are reducing their labour force and therefore decreasing the opportunity for the youth to get into possible employment. It appears that there has been a decrease in one of the major employment sectors for the youth in Zambia since the advent of privatization (Sikamo, et al., 2015 ) and the intervention of technology. Figure 3 below shows these statistics and will be used for interpretation of the implications. 


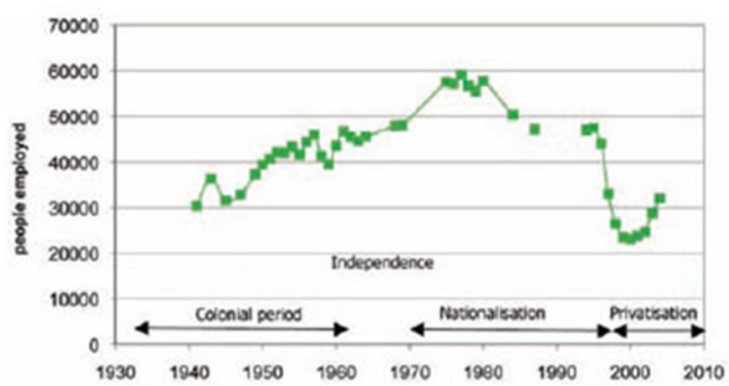

Figure 2-Employment in the mines of the Zamblan Copperbelt (data: references $2,3,4,5$
Figure 4: Decreasing employment levels since nationalization of mines Source: (SciELOSA 2011)

The decreasing unemployment levels in the major sectors of the Zambian economy present the youth with huge challenges of survival and in the end they are co-opted into vices of political violence and illegal dealings in order to make ends meet. Youth unemployment in Zambia therefore becomes more of a curse and a cost. The youth are therefore referred to as a lost generation

\section{Youth unemployment a curse and a cost}

Youth unemployment is a huge cost to any country as this represents the most active productive age that would add more value to the economy of many countries including Zambia. Research has shown that the high youth unemployment levels indicate lower earnings and reduced productivity (Kilimani, 2017). Economies across the globe have been known to be dominated by the middle-income class, which has the spending power. When the earnings in the middle-income class reduce, it has adverse effects on the growth of the economy as aggregate demand dwindles. Studies by Mulungu and Ng'ombe (2017) indicate that sectors such as mining and manufacturing in Zambia are a huge source of economic development and in reality these are the sectors that employ mostly the productive ages, the youth (Mulungu \& Ng'ombe, 2017).

The cost of not employing the youth in Zambia is therefore an opportunity cost in economic growth as it represents potential lost income in the form of lost tax revenue and consumption power. This presents itself as a curse since the larger population is unemployed and engaged in non-tax contributing activities.

\section{The curse of the unemployed youth}

The Zambian government recently increased the minimum pensionable age from 55 to 65 years (Mukanga, 2013). The government's argument was that the lower minimum age discriminated against those employees who wanted to work for longer periods. On the other hand, economists have argued that increasing the minimum retirement or pensionable age is not good as most people at 55 are unable to venture into personal entrepreneurship to create wealth for themselves and contribute to employment creation. This adjustment in the law by the government is also seen as one that reduces employment opportunities for the youth. However, some observers believe delay in paying retirement benefits is a way for government to buy time and have access to funds for more projects. The United Nations world mortality report indicates that Africa has a lower mortality rate in comparison to the rest of world, which stands at $16 \%$ of the world population (World population prospects, 2017). Zambia's life expectancy rate according to Gazetteer stands at 53.74 years (Gazetter, 2018).

The life expectancy in Zambia of 54 years is below the minimum retirement age of 65 years and this means that most people would have died before they access their retirement packages, most of which in Zambia are often never paid. The Central Statistics Office (CSO) indicated that youth unemployment stood at $19.3 \%$ (Central Statistics Office, 2018). This indicates that chances for youth employment are still very low in Zambia and that the youth will continue wallowing in poverty and engaging themselves in criminal activities in order for them to sustain their lives. Political violence involving the youth seems to take centre stage and the assumption is that the youth have no jobs and no businesses to run and therefore they are used in politics as instruments of violence.

\section{Alcohol abuse and the Youth}

The other vice that is affecting the Youth is alcohol abuse. According to the World Health Organization, there is a prevalence of alcohol abuse of people above the age of 15 as the indicators are that $7.9 \%$ are male and $1.0 \%$ are female (World Health Organisation, 2014). The prevalence of alcohol abuse is in the productive age and this is an indicator of the youth not engaged in productive sectors. The problem of Youth alcohol abuse is not only a Zambian problem but also in South Africa, $80 \%$ of youth deaths are alcohol- and drug-related (Parker, 2017). In both Zambia and South Africa, youth unemployment rates are very high, hence this could be attributed to the curse of youth unemployment 


\section{Conclusion}

The literature interrogated in this research indicates that youth unemployment is increasing in Zambia and also that the key sectors such as mining and agriculture are reducing their volumes of production and therefore needing less and less youth labour because of using more capital-intensive methods of production. This means that if there are no deliberate efforts by government to create jobs and business opportunities for the youth, Zambia could be facing both an economic and social crises. The policies and laws put in place by the Zambian government such as increasing the pensionable age and introducing costly minimum wage bills could result in reduced chances of youth employment. Unless government puts in place measures to reduce cost of production and business, youth unemployment will remain high. The government needs to reduce the cost of capital and invest in entrepreneurship training in order that more youths can venture into businesses in key sectors and employ more people in the lower age bracket. Deliberate intervention strategies need to be crafted to arrest the dire situation.

Statistics clearly show that Africa still has a higher mortality rate and they indicate that unemployment is a major problem globally but must be put on the top of the economic agenda. Youth unemployment in Zambia has a negative effect on economic growth and in conclusion, it is a curse and a cost anywhere in the world.

\section{References}

Anti-corruption commission, 2013. CEEC Directors Arrested in corruption allegations, Lusaka: Lusaka Times.

Baah-Boateng, W., 2016. The youth unemployment challenge in Africa: What are the drivers?. Sage Journals, 4(27), pp. 413-431.

Bell, D. N. \& Blanch flower, G. D., 2009. dartmouth.edu. [Online] Available at: https://www.dartmouth.edu/ blnchflr/papers/Youth\%209-1.pdf

[Accessed 05 May 2019].

Bhorat, H. et al., 2015. Youth employment challenges, Ottawa: International Development Research Centre.

Bloomberg, 2018. Zambia's economic performance, New York: Bloomberg.

Caruso, R. \& Gavrilova, E., 2012. Youth Unemployment, Terrorism and Political Violence, Evidence from the Israeli/Palestinian Conflict. Peace Economics Peace Science and Public Policy, 18(2).

Central Statistics Office, 2018. Zambia in figures, Lusaka: Central statistics Office.

Gazetter, 2018. Population 2018, s.1.: geoba.se.

Haabazoka, L., Kamanga, P. S., Sichinsambwe, C. \& Kapena, S., 2016. A study of the challenges of youth unemployment in Zambia. International Journal of Commerce and Management Research, 2(6), pp. 41-46.

Hilker, D. L. M., 2015. "Violence, peace and stability: The youth factor. UNICEF.

ILO, 2017. Zambia's Employment Outlook: Diversification, Formalization and Education, Geneva: Employment Policy Department.

Kilimani, N., 2017. Youth Employment in Developing Economies: Evidence on Policies and Interventions. IDS Bulletin, 48(3).

Ministry of Labour, 2017. Zambia Labour force survey, Lusaka: Minsitry of labour.

Ministry of youth and sport, 2015. myscd.gov.zm. [Online] Available at: http://www.myscd.gov.zm/?wpfb_dl=46[Accessed 02 May 2019].

Mukanga, C., 2013. Raising the Retirement Age in Zambia. Zambian Economist.

Mulungu, K. \& Ng'ombe, J. . . N., 2017. Sources of Economic Growth in Zambia, 1970-2013: A Growth Accounting Approach. Economies-MDP, 5(15), pp. 2-23.

Ndulo, M., 2014. Review of the Anti-corruption Legal Framework in Zambia, Lusaka: SAIPAR Bookshelf.

Oliver, $\quad$ M., 2016. http:/dspace.unza.zm. [Online] Available at: http://dspace.unza.zm:8080/xmlui/bitstream/handle/123456789/5052/MAIN\%20DOCUMENT.pdf?sequenc $\mathrm{e}=1 \&$ isAllowed $=\mathrm{y}$ [Accessed 04 May 2019].

Oluwajodu, F., Blaauw, D., Greyling, L. \& Kleynhan, E. P., 2015. Graduate unemployment in South Africa: Perspectives from the banking sector. SA Journal of Human Resources Development, 13(1).

Parker, B., 2017. 80\% of SA's male youth deaths are alcohol-related and drug consumption is twice the world norm, Pretoria: Parents 24.

Petrongolo, B. \& Reenen, J. V., 2011. http://cep.lse.ac.uk. [Online] Available at: http://cep.lse.ac.uk/pubs/download/cp338.pdf [Accessed 05 May 2019].

Sikamo, J., Mwanza, A. \& Mweemba, C., 2015. saimm.co.za. [Online] Available at: https://www.saimm.co.za/Conferences/BM2015/001-Sikamo.pdf [Accessed 0505 2019].

World Bank, 2017. World population report, Geneva: World Bank.

World Health Organisation, 2014. WHO health report 2014, Zambia: WHO.

World population prospects, 2017. World Mortality 2017, New York: United Nations. 